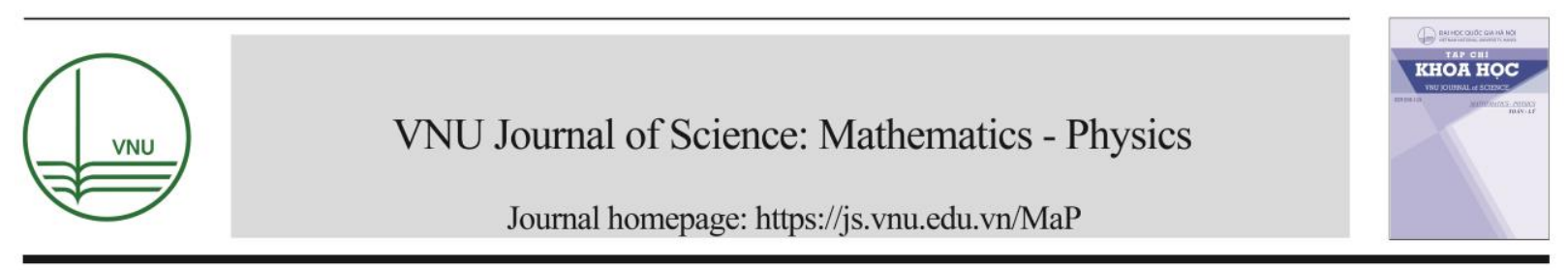

\title{
Synthesis and Optical Properties of $\mathrm{ZnAl}_{2} \mathrm{O}_{4} / \mathrm{Al}_{2} \mathrm{O}_{3}: \mathrm{Cr}^{3+}$ Composite Materials
}

\author{
Trinh Thi Loan", Nguyen Ngoc Long \\ Faculty of Physics, VNU University of Science, 334 Nguyen Trai, Thanh Xuan, Hanoi, Vietnam \\ Received 16 January 2018 \\ Revised 02 February 2018; Accepted 15 March 2018
}

\begin{abstract}
Zinc aluminate - alumina $\left(\mathrm{ZnAl}_{2} \mathrm{O}_{4} / \mathrm{Al}_{2} \mathrm{O}_{3}\right)$ systems doped with $\mathrm{Cr}^{3+}$ different concentrations were synthesized by sol-gel method. The samples were characterized by X-ray diffraction (XRD), photoluminescence (PL) and photoluminescence excitation (PLE) spectra. The results showed that $\mathrm{Cr}^{3+}$ dopant concentration had a significant effect on the lattice constants of $\mathrm{ZnAl}_{2} \mathrm{O}_{4} / \mathrm{Al}_{2} \mathrm{O}_{3}$ composite and their luminescence characteristics. When increasing $\mathrm{Cr}^{3+}$ contents, the lattice constants of both the $\mathrm{ZnAl}_{2} \mathrm{O}_{4}$ and $\alpha-\mathrm{Al}_{2} \mathrm{O}_{3}$ crystals increase. For the samples with low $\mathrm{Cr}^{3+}$ dopant concentrations, the PL spectra mainly consist of sharp lines assigned to the ${ }^{2} \mathrm{E}\left({ }^{2} \mathrm{G}\right) \rightarrow{ }^{4} \mathrm{~A}_{2}\left({ }^{4} \mathrm{~F}\right)$ transitions of $\mathrm{Cr}^{3+}$ ions located in strong octahedral field of the $\mathrm{ZnAl}_{2} \mathrm{O}_{4}$ and $\alpha-$ $\mathrm{Al}_{2} \mathrm{O}_{3}$ crystals. With increasing $\mathrm{Cr}^{3+}$ concentration, in the PL spectra appears very broad emission band in the long-wavelength side, which originates from the ${ }^{4} \mathrm{~T}_{2}\left({ }^{4} \mathrm{~F}\right) \rightarrow{ }^{4} \mathrm{~A}_{2}\left({ }^{4} \mathrm{~F}\right)$ transitions within the $\mathrm{Cr}^{3+}$ ions located in the weak octahedral sites of the $\mathrm{ZnAl}_{2} \mathrm{O}_{4}$ and $\alpha-\mathrm{Al}_{2} \mathrm{O}_{3}$ crystals.
\end{abstract}

Keywords: Zinc aluminate - alumina composite, sol-gel, photoluminescence.

\section{Introduction}

Of all the materials made by man, ceramics have the longest history. Mixed metal oxides with spinel type structure are an important range of ceramic compounds with great interesting electrical, mechanical and optical properties [1]. In recent years, significant efforts have been made by several research groups on the synthesis and characterization of $\mathrm{Cr}^{3+}$ doped various host materials [2]. Because the band gaps of spinels with oxygen anions are rather wide, this circumstance allows for efficient doping with transition metal ions and the crystals with spinel structure are interesting host lattices for $\mathrm{Cr}^{3+}$ doping [3]. In the present study, spinel-type $\mathrm{ZnAl}_{2} \mathrm{O}_{4} / \mathrm{Al}_{2} \mathrm{O}_{3}$ mixed metal oxides doped with $\mathrm{Cr}^{3+}$ different concentrations were synthesized by sol-gel method using $\mathrm{ZnCl}_{2}, \mathrm{Al}\left(\mathrm{NO}_{3}\right)_{3} \cdot 9 \mathrm{H}_{2} \mathrm{O}$ and $\mathrm{CrCl}_{3} \cdot 6 \mathrm{H}_{2} \mathrm{O}$ aqueous solutions as the precursors. The synthesized samples were characterized by $\mathrm{X}$-ray diffraction (XRD), photoluminescence (PL) and photoluminescence excitation (PLE) spectra.

\footnotetext{
* Corresponding author. Tel.: 84-904367699.

Email: loan.trinhthi@gmail.com

https//doi.org/ 10.25073/2588-1124/vnumap.4253
} 


\section{Experimental}

The $\mathrm{ZnAl}_{2} \mathrm{O}_{4} / \mathrm{Al}_{2} \mathrm{O}_{3}$ mixed metal oxides doped with $\mathrm{Cr}^{3+}$ contents ranging from 1 to $25 \mathrm{~mol} \%$ have been synthesized by a sol-gel method. First aqueous solutions from $\mathrm{ZnCl}_{2}, \mathrm{Al}\left(\mathrm{NO}_{3}\right)_{3} .9 \mathrm{H}_{2} \mathrm{O}$ and $\mathrm{CrCl}_{3} \cdot 6 \mathrm{H}_{2} \mathrm{O}$ were prepared and then citric acid solution was added to the above solution. The last mixed solution was kept at constant temperature of $70{ }^{\circ} \mathrm{C}$ until a highly viscous gel was formed. After drying in air at $220{ }^{\circ} \mathrm{C}$ for $5 \mathrm{~h}$, the gel was converted to a xerogel more opaque and dense. The xerogel was annealed at a temperature of $1200{ }^{\circ} \mathrm{C}$ in air for $3 \mathrm{~h}$.

The crystal structure of the samples was characterized by a Siemens D5005 Bruker, Germany Xray diffractometer (XRD) with $\mathrm{Cu}-\mathrm{K}_{a 1}(\lambda=1.54056 \AA)$ irradiation. The composition of the samples was determined by an energy-dispersive X-ray spectrometer (EDS) Oxford Isis 300 attached to the JEOL-JSM 5410 LV scanning electron microscope. Photoluminescence (PL) and photoluminescence excitation (PLE) spectra were measured at room temperature using a Fluorolog FL3-22 Jobin Yvon Spex, USA spectrofluorometer with a xenon lamp of $450 \mathrm{~W}$ being used as an excitation source.

\section{Result and discussion}

Fig. 1 shows the XRD patterns of the $\mathrm{ZnAl}_{2} \mathrm{O}_{4}$ and $\mathrm{ZnAl}_{2} \mathrm{O}_{4} / \mathrm{Al}_{2} \mathrm{O}_{3}$ samples doped with 1 mol\% $\mathrm{Cr}^{3+}$. The $1 \mathrm{~mol} \% \mathrm{Cr}^{3+}$-doped $\mathrm{ZnAl}_{2} \mathrm{O}_{4}$ sample possesses a typical $\mathrm{ZnAl}_{2} \mathrm{O}_{4}$ single crystal structure with peaks at $2 \theta$ of $31.3^{\circ}, 36.9^{\circ}, 44.9^{\circ}, 49.1^{\circ}, 55.7^{\circ}, 59.4^{\circ}$ and $65.3^{\circ}$ corresponding to (220), (311), (400), (331), (422), (511) and (440) planes (JCPDS card: 05-0669). No peaks of other phase were detected (Fig. 1, line a). Meanwhile, the $1 \mathrm{~mol} \% \mathrm{Cr}^{3+}$ doped- $\mathrm{ZnAl}_{2} \mathrm{O}_{4} / \mathrm{Al}_{2} \mathrm{O}_{3}$ sample containing a small amount of $\alpha-\mathrm{Al}_{2} \mathrm{O}_{3}$ exhibits some diffraction peaks from $\alpha-\mathrm{Al}_{2} \mathrm{O}_{3}$ (Fig. 1, line b). The characteristic peaks of $\alpha-\mathrm{Al}_{2} \mathrm{O}_{3}$ phase at $2 \theta$ of $25.6^{\circ}, 35.2^{\circ}, 37.8^{\circ}, 43.9^{\circ}, 52.6^{\circ}, 57.6^{\circ}$ and $68.3^{\circ}$ are corresponding to (012), (104), (110), (113), (024), (116) and (300) diffraction planes (JCPDS card: 46-1212). The average lattice constants of the $\mathrm{ZnAl}_{2} \mathrm{O}_{4}$ spinel calculated from the XRD patterns of the $\mathrm{ZnAl}_{2} \mathrm{O}_{4}$ and $\mathrm{ZnAl}_{2} \mathrm{O}_{4} / \mathrm{Al}_{2} \mathrm{O}_{3}$ samples doped with $1 \mathrm{~mol} \% \mathrm{Cr}^{3+}$ are $8.073 \AA$ and $8.072 \AA$, respectively. To find out the effect of $\mathrm{Cr}^{3+}$ dopant concentration on the structural of the synthesized samples, the XRD patterns of the samples with different doping concentrations were investigated as shown in Fig. 2.

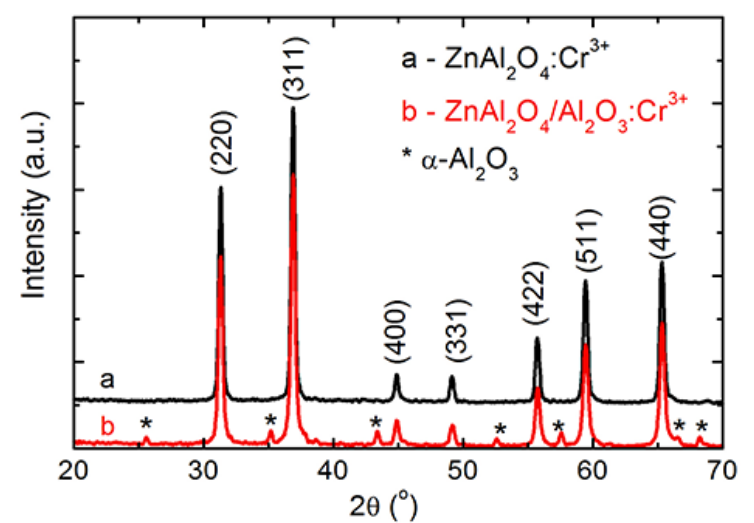

Fig. 1. XRD patterns of the (a) $\mathrm{ZnAl}_{2} \mathrm{O}_{4}: \mathrm{Cr}^{3+}$ and (b) $\mathrm{ZnAl}_{2} \mathrm{O}_{4} / \mathrm{Al}_{2} \mathrm{O}_{3}: \mathrm{Cr}^{3+}$ samples. $\mathrm{Cr}^{3+}$ content is $1 \mathrm{~mol} \%$.

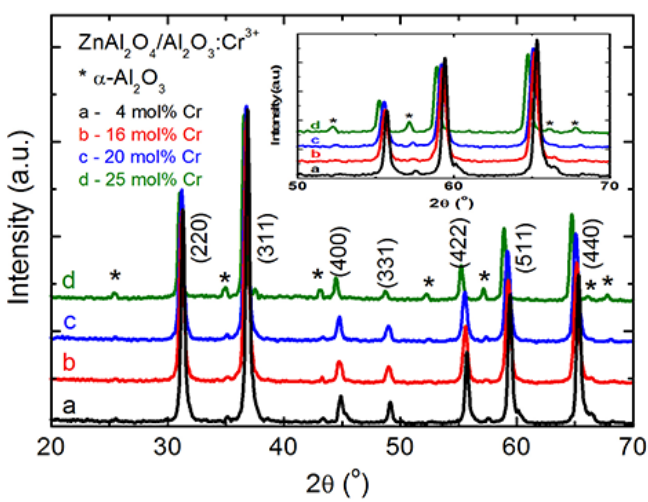

Fig. 2. XRD patterns of the $\mathrm{Cr}^{3+}$-doped $\mathrm{ZnAl}_{2} \mathrm{O}_{4} / \mathrm{Al}_{2} \mathrm{O}_{3}$ samples with different doping concentrations. Inset shows displacement of the diffraction peaks. 
Table 1. The lattice constants of $\mathrm{ZnAl}_{2} \mathrm{O}_{4}$ spinel with different doping concentrations.

\begin{tabular}{lllllll}
\hline $\begin{array}{l}\mathrm{Cr}^{3+} \text { content } \\
(\mathrm{mol} \%)\end{array}$ & $\mathrm{d}_{220}$ & $\mathrm{~d}_{311}$ & $\mathrm{~d}_{422}$ & $\mathrm{~d}_{511}$ & $\mathrm{~d}_{440}$ & $a=b=c(\AA)$ \\
\hline 1 & 2.855 & 2.434 & 1.648 & 1.553 & 1.427 & $8.072 \pm 0.001$ \\
4 & 2.855 & 2.435 & 1.649 & 1.554 & 1.427 & $8.075 \pm 0.001$ \\
16 & 2.861 & 2.441 & 1.652 & 1.558 & 1.431 & $8.093 \pm 0.001$ \\
20 & 2.864 & 2.442 & 1.653 & 1.559 & 1.432 & $8.100 \pm 0.001$ \\
25 & 2.878 & 2.454 & 1.662 & 1.566 & 1.439 & $8.140 \pm 0.001$ \\
\hline
\end{tabular}

Table 2. The lattice constants of $\alpha-\mathrm{Al}_{2} \mathrm{O}_{3}$ sample with different doping concentrations.

\begin{tabular}{llllll}
\hline $\begin{array}{l}\mathrm{Cr}^{3+} \text { content } \\
(\mathrm{mol} \%)\end{array}$ & $\mathrm{d}_{104}$ & $\mathrm{~d}_{113}$ & $\mathrm{~d}_{116}$ & $a=b(\AA)$ & $c(\AA)$ \\
\hline 1 & 2.548 & 2.083 & 1.510 & $4.769 \pm 0.017$ & $12.94 \pm 0.03$ \\
16 & 2.552 & 2.088 & 1.604 & $4.779 \pm 0.017$ & $12.97 \pm 0.03$ \\
25 & 2.562 & 2.097 & 1.611 & $4.795 \pm 0.012$ & $13.03 \pm 0.03$ \\
\hline
\end{tabular}

It is clearly seen that with increasing $\mathrm{Cr}^{3+}$ content, the position of the diffraction peaks of both $\mathrm{ZnAl}_{2} \mathrm{O}_{4}$ and $\alpha-\mathrm{Al}_{2} \mathrm{O}_{3}$ phases is shifted towards the small $2 \theta$ side (Inset of Fig. 2), which is associated with an increase in the $d_{\mathrm{hkl}}$ and the lattice constants. This is because in octahedral sites, the effective ionic radius of $\mathrm{Cr}^{3+}(0.615 \AA)$ is larger than that of $\mathrm{Al}^{3+}(0.535 \AA)$. In addition, none of diffraction peaks corresponding to chromium oxide have been observed in the XRD patterns. This proves that the $\mathrm{Cr}^{3+}$ ions have replaced some portion of $\mathrm{Al}^{3+}$ ions in both $\mathrm{ZnAl}_{2} \mathrm{O}_{4}$ and $\alpha-\mathrm{Al}_{2} \mathrm{O}_{3}$ lattices. The lattice constants of the $\mathrm{ZnAl}_{2} \mathrm{O}_{4}$ and $\alpha-\mathrm{Al}_{2} \mathrm{O}_{3}$ phases calculated from the XRD patterns are shown in Tables 1 and 2 , respectively.

The EDS spectra of the $\mathrm{ZnAl}_{2} \mathrm{O}_{4} / \mathrm{Al}_{2} \mathrm{O}_{3}$ samples doped with 1,16 and $20 \mathrm{~mol} \% \mathrm{Cr}^{3+}$ are presented in Fig. 3. The EDS spectra exhibit the peaks related to the $\mathrm{Al}, \mathrm{Zn}, \mathrm{O}$ and $\mathrm{Cr}$ elements, in addition, the characteristic peaks for $\mathrm{Cr}$ element increase in intensity when $\mathrm{Cr}^{3+}$ concentration increases. The results of the EDS and XRD analysis indicate that the $\mathrm{Cr}^{3+}$ ions are incorporated in $\mathrm{Al}^{3+}$ lattice sites.
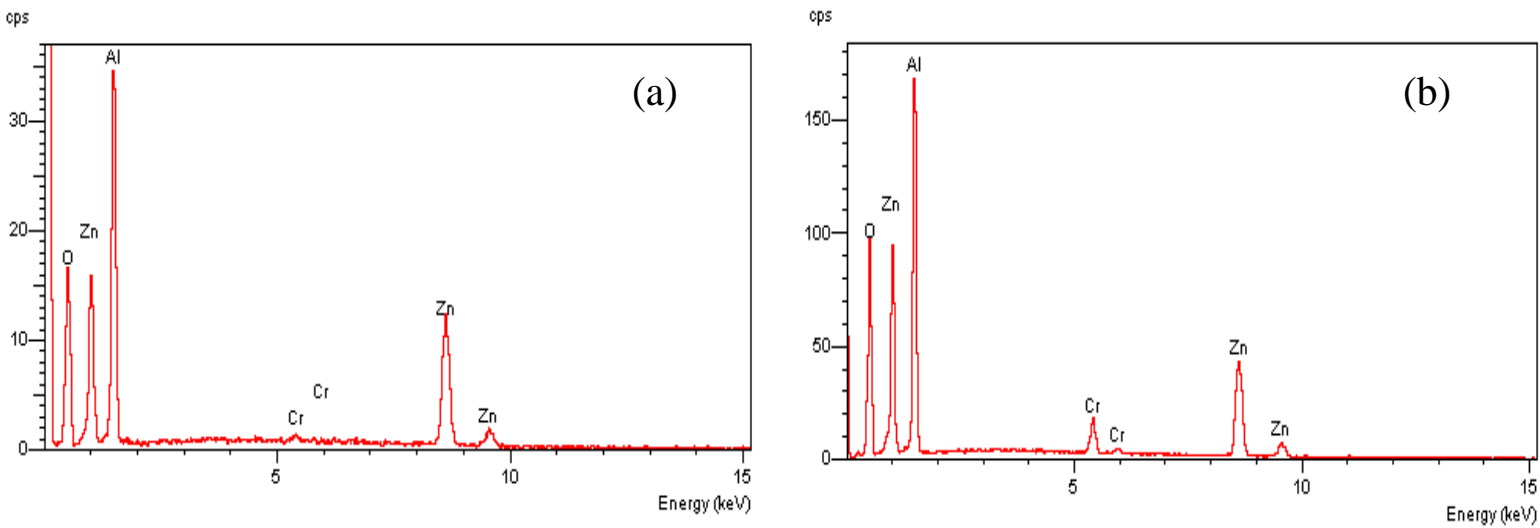


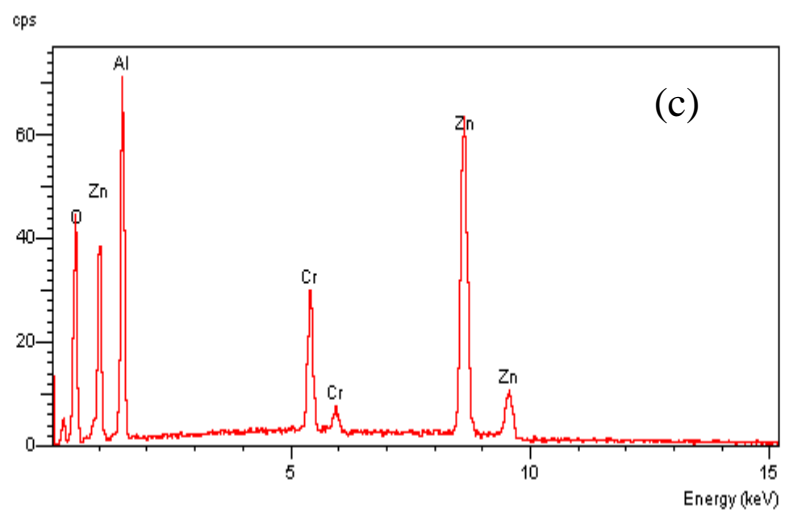

Fig. 3. The EDS spectra of the $\mathrm{Cr}^{3+}$-doped $\mathrm{ZnAl}_{2} \mathrm{O}_{4} / \mathrm{Al}_{2} \mathrm{O}_{3}$ samples with different doping concentrations. a) $1 \mathrm{~mol} \mathrm{\%} \mathrm{Cr,} \mathrm{b)} 16 \mathrm{~mol} \% \mathrm{Cr}$ and c) $20 \mathrm{~mol} \% \mathrm{Cr}$.

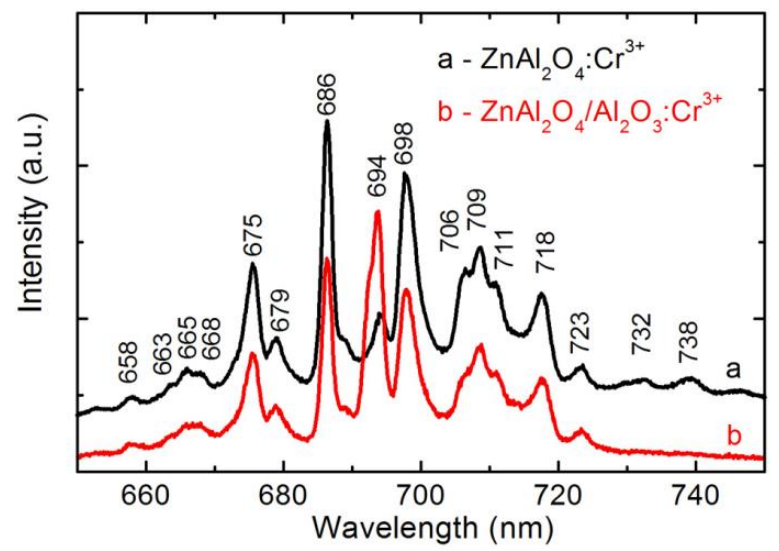

Fig. 4. PL spectra of the (a) $\mathrm{ZnAl}_{2} \mathrm{O}_{4}: \mathrm{Cr}^{3+}$ and (b) $\mathrm{ZnAl}_{2} \mathrm{O}_{4} / \mathrm{Al}_{2} \mathrm{O}_{3}: \mathrm{Cr}^{3+}$ samples excited by $552 \mathrm{~nm}$ wavelength. $\mathrm{Cr}^{3+}$ content is $1 \mathrm{~mol} \%$.

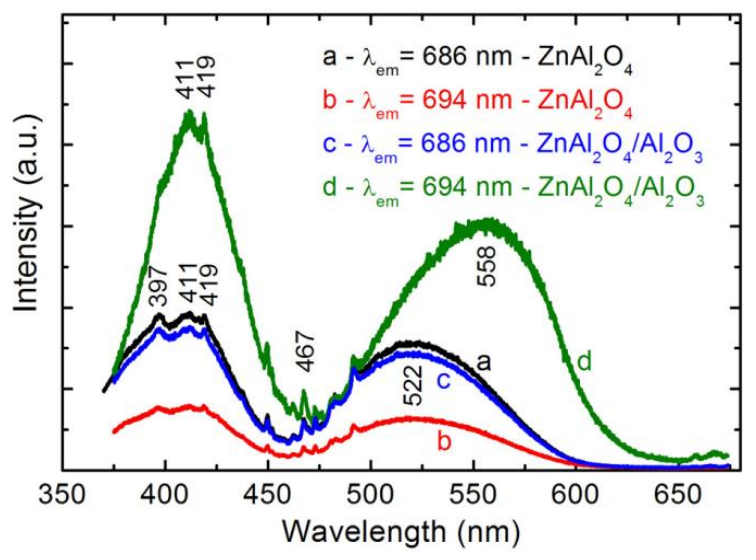

Fig. 5. PLE spectra of the $\mathrm{ZnAl}_{2} \mathrm{O}_{4}: \mathrm{Cr}^{3+}$ and $\mathrm{ZnAl}_{2} \mathrm{O}_{4} / \mathrm{Al}_{2} \mathrm{O}_{3}: \mathrm{Cr}^{3+}$ samples monitored at $686 \mathrm{~nm}$ and $694 \mathrm{~nm}$.

Fig. 4 shows the PL spectra of the $\mathrm{ZnAl}_{2} \mathrm{O}_{4}$ and $\mathrm{ZnAl}_{2} \mathrm{O}_{4} / \mathrm{Al}_{2} \mathrm{O}_{3}$ samples doped with $1 \mathrm{~mol} \% \mathrm{Cr}^{3+}$ excited by $552 \mathrm{~nm}$ wavelength. In the spectrum of the $\mathrm{ZnAl}_{2} \mathrm{O}_{4}: \mathrm{Cr}^{3+}$ sample, a zero-phonon R-line with the strongest intensity at $686 \mathrm{~nm}$ corresponding to the ${ }^{2} \mathrm{E}\left({ }^{2} \mathrm{G}\right) \rightarrow{ }^{4} \mathrm{~A}_{2}\left({ }^{4} \mathrm{~F}\right)$ transition and the phonon-sidebands of the R-line (R-PSB) at 658, 663, 665, 668, 675, 679, 694, 698, 706, 709, 711, $718,723,732$ and $738 \mathrm{~nm}$ were observed (Fig. 3, line a) [4]. In the PL spectrum of the $\mathrm{ZnAl}_{2} \mathrm{O}_{4} / \mathrm{Al}_{2} \mathrm{O}_{3}$ : $\mathrm{Cr}^{3+}$, we also observed emission lines at $658,663,665,668,675,679,686,694,698,706,709,711$, 718 and $723 \mathrm{~nm}$ (Fig. 3, line b). However, in this case the strongest emission line is at $694 \mathrm{~nm}$ instead of $686 \mathrm{~nm}$ line in the $\mathrm{ZnAl}_{2} \mathrm{O}_{4}: \mathrm{Cr}^{3+}$ sample.

For identification of origin of the emission lines at 686 and $694 \mathrm{~nm}$ of the $\mathrm{ZnAl}_{2} \mathrm{O}_{4} / \mathrm{Al}_{2} \mathrm{O}_{3}: \mathrm{Cr}^{3+}$ sample, the PLE spectra monitored at these emission lines in both the $\mathrm{ZnAl}_{2} \mathrm{O}_{4}: \mathrm{Cr}^{3+}$ and $\mathrm{ZnAl}_{2} \mathrm{O}_{4} / \mathrm{Al}_{2} \mathrm{O}_{3}: \mathrm{Cr}^{3+}$ samples were investigated and are shown in Fig 5. The results show that the PLE spectrum monitored at $686 \mathrm{~nm}$ of the $\mathrm{ZnAl}_{2} \mathrm{O}_{4} / \mathrm{Al}_{2} \mathrm{O}_{3}: \mathrm{Cr}^{3+}$ sample is similar to those recorded at 686 
$\mathrm{nm}$ and $694 \mathrm{~nm}$ lines of the $\mathrm{ZnAl}_{2} \mathrm{O}_{4}: \mathrm{Cr}^{3+}$ sample (Fig. 5, lines a, b, and c), the PLE spectra consist of two strong broad bands. The broad band centered at $522 \mathrm{~nm}$ corresponds to ${ }^{4} \mathrm{~A}_{2}\left({ }^{4} \mathrm{~F}\right) \rightarrow{ }^{4} \mathrm{~T}_{2}\left({ }^{4} \mathrm{~F}\right)$ transitions, meanwhile three bands centered at 397,411 and $419 \mathrm{~nm}$ correspond to ${ }^{4} \mathrm{~A}_{2}\left({ }^{4} \mathrm{~F}\right) \rightarrow{ }^{4} \mathrm{~T}_{1}\left({ }^{4} \mathrm{~F}\right)$ transitions [4, 5]. In addition, the weak band at $467 \mathrm{~nm}$ is assigned to ${ }^{4} \mathrm{~A}_{2}\left({ }^{4} \mathrm{~F}\right) \rightarrow{ }^{4} \mathrm{~T}_{2}\left({ }^{2} \mathrm{G}\right)$ transition [5]. The above results indicate that the emission line at $686 \mathrm{~nm}$ of the $\mathrm{ZnAl}_{2} \mathrm{O}_{4} / \mathrm{Al}_{2} \mathrm{O}_{3}: \mathrm{Cr}^{3+}$ sample corresponding to the ${ }^{2} \mathrm{E}\left({ }^{2} \mathrm{G}\right) \rightarrow{ }^{4} \mathrm{~A}_{2}\left({ }^{4} \mathrm{~F}\right)$ transition within the $\mathrm{Cr}^{3+}$ ions located in the $\mathrm{ZnAl}_{2} \mathrm{O}_{4}$ octahedral crystal field (R-line). It can be seen from line d (Fig. 5) that the broad excitation band in the PLE spectrum monitored at the $694 \mathrm{~nm}$ line of the $\mathrm{ZnAl}_{2} \mathrm{O}_{4} / \mathrm{Al}_{2} \mathrm{O}_{3}: \mathrm{Cr}^{3+}$ sample locates at $558 \mathrm{~nm}$, i.e. is shifted towards the longer-wavelength side by $36 \mathrm{~nm}$ in comparison with lines a, b, c (Fig. 5). The above results prove that the line at $694 \mathrm{~nm}$ arises from other center than the line at $686 \mathrm{~nm}$.

The PL spectrum of the $\mathrm{ZnAl}_{2} \mathrm{O}_{4} / \mathrm{Al}_{2} \mathrm{O}_{3}$ sample doped with $1 \mathrm{~mol} \% \mathrm{Cr}^{3+}$ excited by $558 \mathrm{~nm}$ wavelength exhibits a very intense line at $694 \mathrm{~nm}$ (Fig. 6). Beside, an emission shoulder at $692 \mathrm{~nm}$ is also observed. It is noticed that the PLE spectrum monitored at $692 \mathrm{~nm}$ (not shown here) is similar to that recorded at $694 \mathrm{~nm}$. The above results prove that for the sample $\mathrm{ZnAl}_{2} \mathrm{O}_{4} / \mathrm{Al}_{2} \mathrm{O}_{3}: \mathrm{Cr}^{3+}$, the shoulder at $692 \mathrm{~nm}$ and the line at $694 \mathrm{~nm}$ arise from same center. According to the results reported by us [6], V. Singh et al. [2] and G. Rani et al. [7], two lines at $692 \mathrm{~nm}$ (noted by $\mathrm{R}_{1}$-line) and $694 \mathrm{~nm}\left(\mathrm{R}_{2}\right.$-line) are well-known due to the $\overline{\mathrm{E}}\left({ }^{2} \mathrm{E}\left({ }^{2} \mathrm{G}\right)\right) \rightarrow{ }^{4} \mathrm{~A}_{2}\left({ }^{4} \mathrm{~F}\right)$ and $2 \overline{\mathrm{A}}\left({ }^{2} \mathrm{E}\left({ }^{2} \mathrm{G}\right)\right) \rightarrow{ }^{4} \mathrm{~A}_{2}\left({ }^{4} \mathrm{~F}\right)$ transitions within the $\mathrm{Cr}^{3+}$ ions located in the $\alpha-\mathrm{Al}_{2} \mathrm{O}_{3}$ octahedral crystal field, respectively.

The similarity of the PLE spectra of the $\mathrm{ZnAl}_{2} \mathrm{O}_{4} / \mathrm{Al}_{2} \mathrm{O}_{3}: \mathrm{Cr}^{3+}$ sample monitored at $686,658,663$, $665,668,675,679,698,706,709,711,718$ and $723 \mathrm{~nm}$ (Fig. 7) shows that the lines at 658, 663, 665, $668,675,679,698,706,709,711,718$ and $723 \mathrm{~nm}$ are phonon-sidebands of the line R.

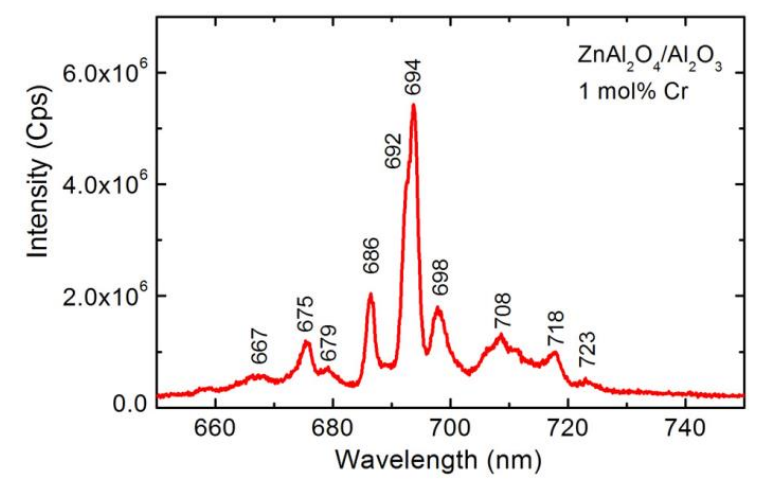

Fig. 6. PL spectrum of the $\mathrm{ZnAl}_{2} \mathrm{O}_{4} / \mathrm{Al}_{2} \mathrm{O}_{3}$ sample doped with $1.0 \mathrm{~mol} \% \mathrm{Cr}^{3+}$ excited by $558 \mathrm{~nm}$ wavelength.

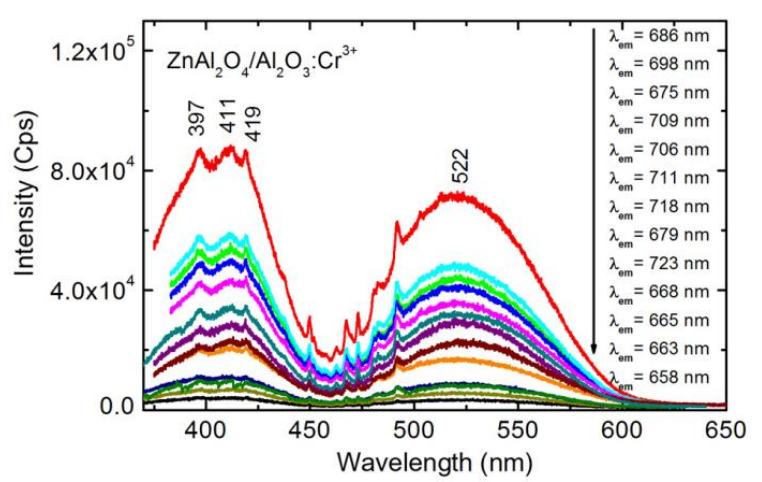

Fig. 7. PLE spectra of the $\mathrm{ZnAl}_{2} \mathrm{O}_{4} / \mathrm{Al}_{2} \mathrm{O}_{3}: \mathrm{Cr}^{3+}$ sample monitored at different wavelengths.

Fig. 8 and Fig. 9 show the PL spectra of the $\mathrm{Cr}^{3+}$-doped $\mathrm{ZnAl}_{2} \mathrm{O}_{4} / \mathrm{Al}_{2} \mathrm{O}_{3}$ samples with different doping concentrations excited by 558 and $522 \mathrm{~nm}$ wavelengths, respectively. As seen from Fig. 8 and Fig. 9, with increasing the $\mathrm{Cr}^{3+}$ dopant concentration to 16 and $20 \mathrm{~mol} \%$, the PL spectra exhibit very broad emission band in the long-wavelength side, beside the sharp line at $694 \mathrm{~nm}$. 


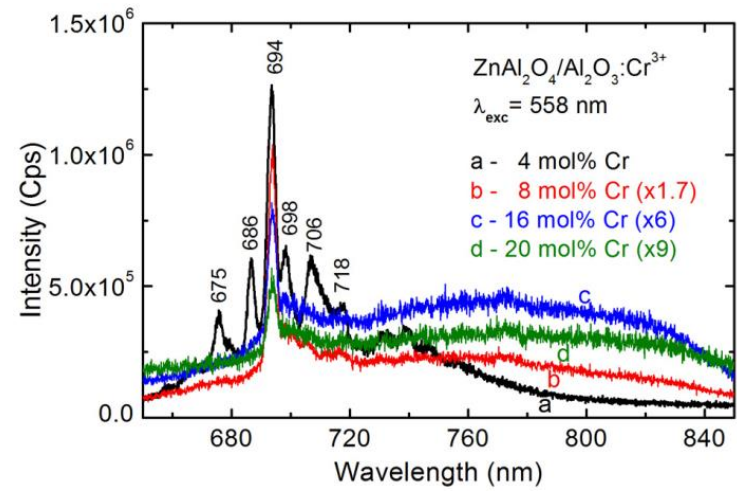

Fig. 8. PL spectra of the $\mathrm{ZnAl}_{2} \mathrm{O}_{4} / \mathrm{Al}_{2} \mathrm{O}_{3}: \mathrm{Cr}^{3+}$ sample with different doping concentrations excited by $558 \mathrm{~nm}$.

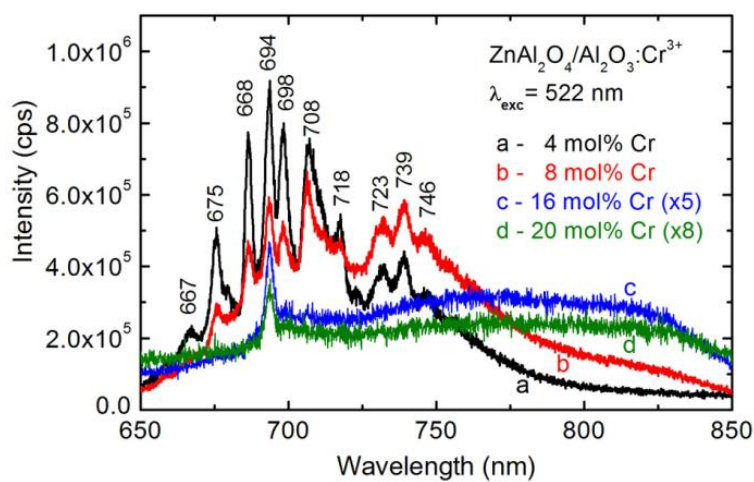

Fig. 9. PL spectra of the $\mathrm{ZnAl}_{2} \mathrm{O}_{4} / \mathrm{Al}_{2} \mathrm{O}_{3}: \mathrm{Cr}^{3+}$ sample with different doping concentrations excited by $522 \mathrm{~nm}$.

It is well known that in the strong octahedral ligand-field, the emission of the $\mathrm{Cr}^{3+}$ ions is characterized by sharp emission lines associated with the ${ }^{2} \mathrm{E}\left({ }^{2} \mathrm{G}\right) \rightarrow{ }^{4} \mathrm{~A}_{2}\left({ }^{4} \mathrm{~F}\right)$ transitions. On the contrary, in the weak octahedral ligand-field, the emission of the $\mathrm{Cr}^{3+}$ ions is characterized by broad luminescence band associated with the ${ }^{4} \mathrm{~T}_{2}\left({ }^{4} \mathrm{~F}\right) \rightarrow{ }^{4} \mathrm{~A}_{2}\left({ }^{4} \mathrm{~F}\right)$ transitions [4]. Additionally, as seen from table 1 and table 2, with increasing the $\mathrm{Cr}^{3+}$ dopant concentration, the lattice constants of both the $\mathrm{ZnAl}_{2} \mathrm{O}_{4}$ and $\alpha-\mathrm{Al}_{2} \mathrm{O}_{3}$ crystals slightly increase, which leads to a decrease in the ligand field surrounding the $\mathrm{Cr}^{3+}$ ions. Therefore, the broad emission bands may be due to the ${ }^{4} \mathrm{~T}_{2}\left({ }^{4} \mathrm{~F}\right) \rightarrow{ }^{4} \mathrm{~A}_{2}\left({ }^{4} \mathrm{~F}\right)$ transitions within the $\mathrm{Cr}^{3+}$ ions located in the weak octahedral crystal fields of $\mathrm{ZnAl}_{2} \mathrm{O}_{4}$ and $\alpha-\mathrm{Al}_{2} \mathrm{O}_{3}$ host lattices. In addition, a large quantity of hanging bonds and defects perhaps exist in the samples with high dopant contents, which further leads to broadening the emission band of the $\mathrm{Cr}^{3+}$ ions towards the long-wavelength side. From Fig. 8 and Fig. 9 it is also clear that the PL intensity is decreased with increasing $\mathrm{Cr}^{3+}$ concentration. This is a common concentration quenching.

\section{Conclusion}

The effect of $\mathrm{Cr}^{3+}$ dopant concentration on the structural and optical properties of the $\mathrm{ZnAl}_{2} \mathrm{O}_{4} / \mathrm{Al}_{2} \mathrm{O}_{3}: \mathrm{Cr}^{3+}$ composite samples have been studied. With increasing $\mathrm{Cr}^{3+}$ contents, the lattice constants of both the $\mathrm{ZnAl}_{2} \mathrm{O}_{4}$ and $\alpha-\mathrm{Al}_{2} \mathrm{O}_{3}$ crystals increase and the ligand-field surrounding $\mathrm{Cr}^{3+}$ ions is decreased. For the samples with low $\mathrm{Cr}^{3+}$ dopant concentrations, the PL spectra mainly consist of sharp lines (R-lines $\left(\mathrm{R}_{1}\right.$ and $\left.\mathrm{R}_{2}\right)$ and R-PSB) assigned to the ${ }^{2} \mathrm{E}\left({ }^{2} \mathrm{G}\right) \rightarrow{ }^{4} \mathrm{~A}_{2}\left({ }^{4} \mathrm{~F}\right)$ transitions of ions $\mathrm{Cr}^{3+}$ located in strong octahedral field of the $\mathrm{ZnAl}_{2} \mathrm{O}_{4}$ and $\alpha-\mathrm{Al}_{2} \mathrm{O}_{3}$ crystals. With increasing $\mathrm{Cr}^{3+}$ concentration, in the PL spectra appears very broad emission band in the long-wavelength side, which originates from the ${ }^{4} \mathrm{~T}_{2}\left({ }^{4} \mathrm{~F}\right) \rightarrow{ }^{4} \mathrm{~A}_{2}\left({ }^{4} \mathrm{~F}\right)$ transitions within the $\mathrm{Cr}^{3+}$ ions located in the weak octahedral sites of the of the $\mathrm{ZnAl}_{2} \mathrm{O}_{4}$ and $\alpha-\mathrm{Al}_{2} \mathrm{O}_{3}$ crystals.

\section{References}

[1] F. Zerarga, A. Bouhemadou, R. Khenata, S. Bin-Omran, Solid State Sciences 13 (2011) 1638-1648 
[2] V. Singh, R.P.S. Chakradhar, J.L. Rao, K. Al-Shamery, M. Haase, Y.-D. Jho, Applied Physics B 107 (2012) 489 495.

[3] M.G. Brik, J. Papan, D.J. Jovanovićd, M.D. Dramićanin, Journal of Luminescence 177 (2016) 145-151.

[4] Trinh Thi Loan, Le Hong Ha, Nguyen Ngoc Long, VNU Journal of Science, Mathematics - Physics 26 (2010) 37-42.

[5] B.S. Ravikumar, H. Nagabhushana, S.C. Sharma, Y.S. Vidya, K.S. Anantharaju, Spectrochimica Acta Part A: Molecular and Biomolecular Spectroscopy 136 (2015) 1027-1037.

[6] Trinh Thi Loan, Nguyen Ngoc Long, and Le Hong Ha, e-Journal of Surface Science and Nanotechnology 9 (2011) 531-535.

[7] G. Rani, P.D. Sahare, Advanced Powder Technology 25 (2014) 767-772. 